\title{
QUALIDADE MICROBIOLÓGICA DE CORPOS D'ÁGUA E SUA RELAÇÃO COM INSEGURANÇA DE COMUNIDADES RURAIS NO SUL DA BAHIA
}

\author{
AUTOR: JULIANA SANTANA GOBBI \\ CO-AUTOR/ORIENTADOR: FLORISVALDA DA SILVA SANTOS
}

\begin{abstract}
Resumo: Propôs-se analisar a qualidade microbiológica da água consumida em comunidades na área de atuação do Projeto "Desenvolvimento Socioambiental para a Agricultura Familiar" (Convênio UFSB Veracel Celulose S.A. No. 23746.000103/2019-67) e sua relação com insegurança hídrica. Contudo, devido às medidas de distanciamento social imposto pela COVID-19, o objetivo deste trabalho foi complementado com uma revisão bibliográfica sobre métodos de monitoramento da qualidade microbiológica da água. Com relação à meta de analisar a qualidade microbiológica da água, foram analisadas 11 (onze) amostras de água para uso residencial, coletadas em março/2020, em reservatórios de 10 propriedades na Associação Miramar, zona rural de Eunápolis/BA. A análise, feita no Laboratório de Microbiologia/CSC/UFSB, usando Membrana filtrante (Standard Methods for the Examination of Water and Wastewater), em triplicatas, detectou a presença de Coliformes Totais e Escherichia coli em todas as amostras. Isto inviabiliza o uso dessas águas para consumo humano sem um rigoroso tratamento do recurso hídrico. Como nenhuma propriedade amostrada tem acesso a sistema de tratamento de água ou à rede de esgotos, os resultados indicam possível risco relacionado à insegurança alimentar (ingestão e uso da água de boa qualidade no preparo e higienização dos alimentos), mas ainda são insuficientes para afirmarem uma situação de risco na segurança hídrica para a comunidade estudada, uma vez que outras dimensões, cada uma delas refletindo as muitas realidades, necessitam de estudos complementares, interrompidos pela pandemia. Com relação à revisão bibliográfica, os métodos de monitoramento da qualidade microbiológica da água mais citados nos 87 periódicos encontrados nas plataformas"Google acadêmico" e "Scielo", entre 2010 e 2019, foram: Tubos múltiplos (43\%), Substrato enzimático (39\%) e Membrana filtrante (17\%). Do ponto de vista prático, Tubos múltiplos têm maior tempo laboral e nível de dificuldade (preparação de material, instrumentos e manuseio da amostra) em relação aos demais. Substrato enzimático tem os menores tempo laboral e nível de dificuldade. Membrana filtrante fornece dados qualitativo (presença e ausência) e quantitativo, sendo este com maior precisão (contagem direta de Unidades formadoras de colônia) que o do Tubos múltiplos, cuja quantificação é estimada pelo Número mais provável, enquanto Substrato enzimático é apenas qualitativo. Tubos múltiplos e Substrato enzimático podem apresentar resultados falsos positivo e negativo.
\end{abstract}

Palavras-chave: Coliformes, Escherichia coli, Qualidade da água. 